\title{
The Omentum in the Treatment of Spinal Cord Injuries
}

\author{
Harry S Goldsmith* \\ University of California, USA
}

Submission: August 14, 2017; Published: August 18, 2017

*Corresponding author: Harry S Goldsmith, MD, Clinical Professor of Neurological Surgery, University of California, USA, Tel: 775-749-5801; Fax: 775-749-5861; Email: hlgldsmith@aol.com

\section{Commentary}

One of the worst disasters that can confront a person is sustaining a spinal cord injury that results in permanent functional disability. Professor Ramon y Cahal stated over a century ago that the reason patients who have sustained a spinal cord injury (SCI) is that scar develops at the site of an SCI, which prevents axons from penetrating through this scar barrier to make direct connections to neurological connections in the distal spinal cord.

This statement by Professor Cahal raised interest in an attempt to develop methods that would prevent the development of a scar in an acute spinal cord injury and, even more difficult, a technique to remove a scar that had already developed in a chronic spinal cord injury. Both challenges have been met and have been reported by Goldsmith HS et al. [1]. In order to prevent a scar in the presence of an acute spinal cord injury, one must simply place a piece of an intact omentum directly on the area of spinal cord injury. Doing this apparently causes the development of a dynamic absorptive equilibrium between the production of edema caused by the spinal cord injury and the absorption of the edema by the overlying omentum. The reason that scar does not develop under this condition is that fibrinogen, which is known to be present in edema fluid, is absorbed by the omentum. Fibrinogen is the initiator of the scar that develops shortly after SCI. It is believed that the absorption of fibrinogen by the omentum is the reason that scar does not develop when the omentum is placed on an SCI.

Removing scar tissue from a chronic spinal cord injury is difficult. However, the removal of scar tissue in the spinal cord can be accomplished. After removing the scar, the gap in the spinal cord that occurs after the removal of a scar is filled with collagen followed by the placement of the omentum directly on the collagen bridge. Axons have been shown to grow through this collagen-omental bridge at the rate of $1 \mathrm{~mm}$ per day in its

progress into the distal spinal cord. This preparation has led to functional improvement in both animals and, more importantly, in a human. Most impressive, it has been shown by serial MRI's that the spinal cord can heal itself without the need of stem cells or drugs. It is hoped that the findings mentioned in this short report will hopefully benefit future patients who have suffered an acute or chronic spinal cord injury.

\section{References}

1. Goldsmith HS (2012) Spinal Surgery: Techniques, Complication Avoidance and Management. Edward C Benzel (Ed.), Elsevier Saunders, Philadelphia, USA, 121: 1183-1187.

Your next submission with Juniper Publishers
will reach you the below assets
- Quality Editorial service
- Swift Peer Review
- Reprints availability
- E-prints Service
- Manuscript Podcast for convenient understanding
- Global attainment for your research
- Manuscript accessibility in different formats
( Pdf, E-pub, Full Text, Audio)
- Unceasing customer service
Track the below URL for one-step submission
https://juniperpublishers.com/online-submission.php

